\title{
BARRIER EFFECT AND CROSS-BORDER COOPERATION. THE SWEDEN-NORWAY INTERREG-A TERRITORIAL EFFECTS
}

\author{
EDUARDO MEDEIROS ${ }^{1}$
}

\begin{abstract}
Historic developments that occurred in the last centuries have affected the barrier effect of national borders in Europe and, consequently, the degree and the intensity of the cooperation between neighbouring countries. However, the establishment of the European Single Market, in the last three decades, has deepened the cross-border cooperation inside the EU Territory. In this respect, the INTERREG-A initiative has played a major role, since 1990. This article intends to shed some light on the progress of the cross-border cooperation in the Swedish-Norwegian border region, and the territorial effects of the INTERREG-A programme in the reduction of the barrier effect along the border in five dimensions (institutional-urban, accessibility, culture-social, environmental-heritage and economy-technology).
\end{abstract}

Keywords: Cross-Border Cooperation (CBC), INTERREG-A, Swedish-Norwegian Border Region (SNBR), territorial cooperation, border regions.

ResUmo - EFEITO BARREIRA E COOPERAÇÃO TRANSFRONTEIRIÇA: EFEITOS TERRITORIAIS DO INTERREG-A SUÉCIA-NORUEGA. Acontecimentos históricos ocorridos nos últimos séculos tiveram uma forte influência na intensidade do efeito barreira presente nas várias fronteiras nacionais na Europa e, consequentemente, no grau de cooperação territorial entre países vizinhos. No entanto, nas últimas três décadas, a criação do Mercado Único Europeu aprofundou o processo de cooperação transfronteiriça no interior do território da UE. Neste artigo, apresentam-se, de modo resumido, alguns resultados da implementação do programa INTERREG-A na Suécia-Noruega, na intensificação do processo de cooperação transfronteiriça e na redução do efeito barreira em cinco dimensões (institucional-urbana, acessibilidade, cultural-social, património-ambiental e economia-tecnologia).

Palavras-chave: Cooperação transfronteiriça (CBC), INTERREG-A, região de fronteira cooperação territorial, regiões de fronteira, Suécia, Noruega.

Recebido: Agosto 2012. Aceite: Junho 2013.

1 Investigador do Centro de Estudos Geográficos da Universidade de Lisboa, IGOT. E-mail: emedeiros@campus.ul.pt 
Résumé - BARRIÈRE ET COOPÉRATION TRANSFRONTALIÈRE: RÉSULTATS TERRITORIAUX DE L'INTERREG-A SUÈDE-NORVÈGE. Les événements des derniers siècles ont eu une forte influence sur l'intensité de l'effet de barrière de plusieurs frontières européennes et, par conséquent, sur le degré de coopération territoriale entre pays voisins. Cependant, la création du Marché Unique Européen a permis une meilleure coopération à l'intérieur de l'UE. On présente ici quelques résultats du programme INTERREG-A Suède-Norvège, qui a permis l'approfondissement et l'intensification de la coopération transfrontalière et la réduction de l'effet de barrière, en tenant en compte de cinq dimensions (institution urbaine, accessibilité, culture et société, patrimoine environnemental, économie et technologie).

Mots-clés: Coopération transfrontalière, INTERREG-A, régions de frontière, coopération territoriale, Suède, Norvège.

$$
\begin{aligned}
& \text { ملخص - التعاون عبر الحدود وحو اجزه: النتانج الإقليمية ل INTERREG-A بين السويد و النرويج. كان لأحداث القرون الماضية تأثير }
\end{aligned}
$$

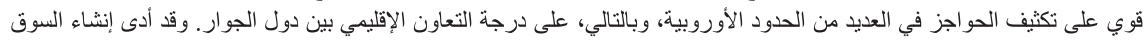

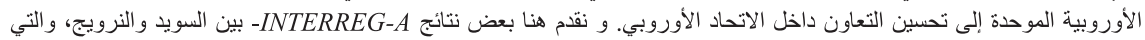

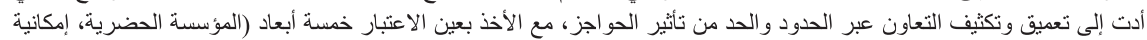

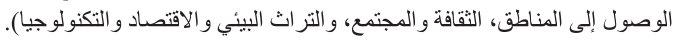

$$
\begin{aligned}
& \text { كلمات البحث: التعاون عبر الحدود، INTERREG ، المناطق الحدودية، التعاون الإقليمي، السويد والنرويج. }
\end{aligned}
$$

\section{INTRODUCTION}

Cross-border cooperation (CBC) plays an important role in boosting the territorial potentials of European regions, and in the correction of the territorial imbalances that still prevail in the European territory. In overall terms, European cross-border regions differ in the degree of integration and identity that arises from many reasons. In the case of the Swedish-Norwegian INTERREG-A Border Region (SNBR - fig. 1), there is a high degree of common identity and also a long tradition in cooperation, that was strengthened by the Treaty of Helsinki (1962), which "provided a further basis for cooperation in legal, cultural, social, economic, transport and environmental issues" (Nordregio, 2007: 89). Furthermore, constant border changes, take-overs, and intermarriages occurred in the past centuries (Lundén, 2004) have provoked changes in the $\mathrm{CBC}$ process in this border area.

Nevertheless, the border is there, and it still affects many aspects of the population which dwell in close proximity of the border area, and also the commuters that cross it on a daily basis, thus preserving a psychological and material separation. To mitigate some of these problems, Sweden and Norway embarked on the INTERREG-A experience in 1995, under the umbrella of the European Regional Policy, providing an opportunity for the local and regional actors, from both sides of the border, to meet and exchange knowledge and experiences, with the purpose of presenting projects related to their field of activity, which could establish strong and sustainable bounds between both sides. 


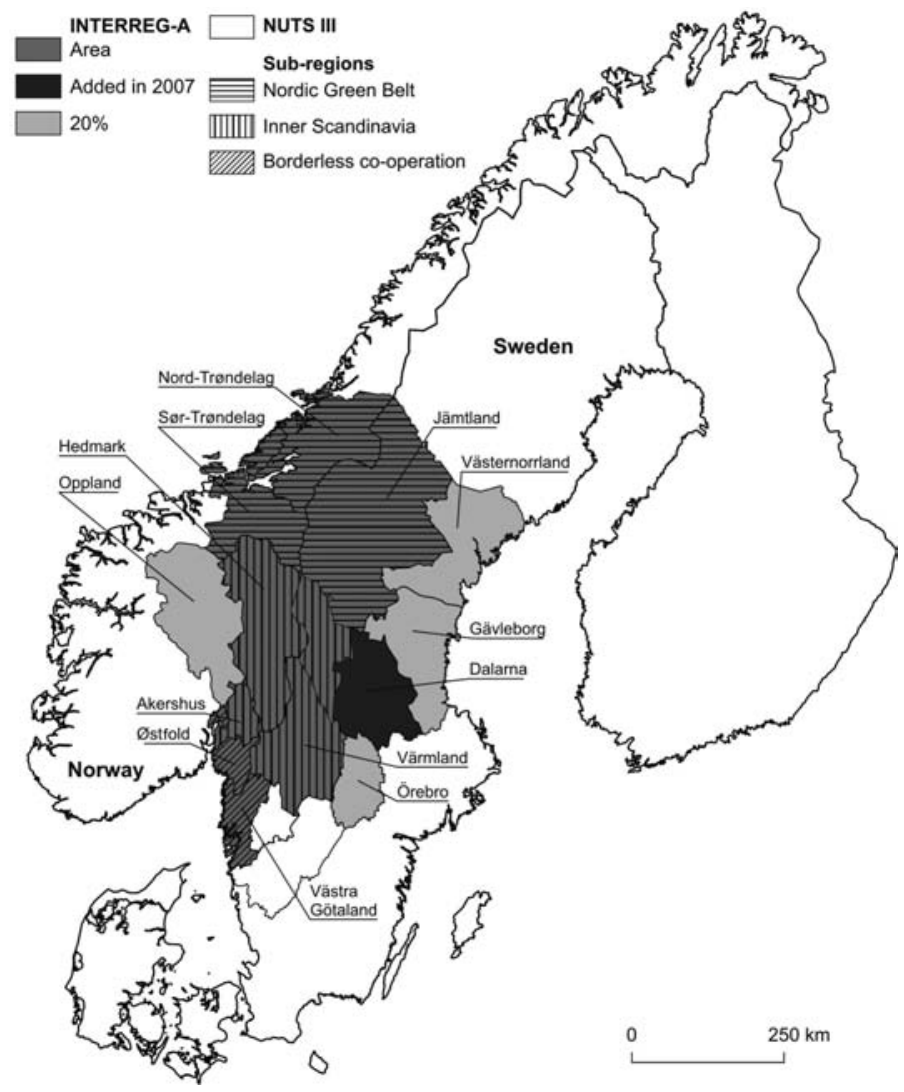

Fig. 1 - SNBR sub-regions and INTERREG-A area.

Fig. 1 - Sub-regiões da SNBR e área do INTERREG-A.

The first INTERREG-A experience (1994-1999) marked a new era in the Swedish-Norwegian CBC process, by introducing new EU formal requirements and regulations, and by increasing the bureaucratization and the withdrawal of some actors which used to participate in pre-INTERREG CBC initiatives (voluntary sector and small enterprises) (Nordregio, 2007). Nevertheless, the experience and maturity of the previously established CBC structures in the SNBR facilitated the set up of the programme which, together with an additional financial boost, brought a new vitality to the Nordic CBC process (Nordregio, 2007). In line with this, the three approved sub-programmes (Nordic Green Belt, Inner Scandinavia and Borderless Co-operation) targeted, as their main goals, the improvement of living conditions and the economic growth in the SNBR (Medeiros, 2010).

When the next generation of this programme started (INTERREG III-A 2000-2006), solid ground foundations for future joint cross-border initiatives, as well as new cross-border contacts and experiences, had already been established, since the 
previous generation had become an important period of learning for all parties involved, in particular in handling EU rules, regulations, routines, project development and project management (EC, 2005; NUTEK, 2003).

The programme moved from an initial phase, which can be labelled as the 'discovering the differences', into a second one marked by a 'strong additionality' of the approved projects (Medeiros, 2010b), which is based on some evaluation reports expressing the clear idea that many relevant projects (more than $70 \%$ ) would not exist without INTERREG funding (EC, 2003; EC, 2005; EC, 2007). In the same vein, the general goals of this generation focused in supporting the economic growth and the living conditions in the border area, in order to reduce the border isolation and promote $\mathrm{CBC}$ on culture, and economic and environmental domains.

Over the last 17 years, the Swedish-Norwegian INTERREG-A programme distributed more than 200 million Euros through more than 500 approved projects, over three sub-regions, in order to ensure that socioeconomic growth is achieved in the border area, as well as improvements in the border dwellers living standards, in a territorially balanced and sustainable development. In this context, the contribution of the programme to reduce the barrier effect in the border area should be regarded as a key aspect of its evaluation. The main contributions of the analysed Swedish-Norwegian INTERREG-A programme in the reduction of this effect in all its dimensions are synthesised on table I.

To achieve this goal, the paper is structured as follows: the first topic covers the analysis of all the dimensions of the barrier effect their relation with the approved Swedish-Norwegian INTERREG-A projects. The second one uses more detailed information by focusing on the analysis of seven projects, in the Inner Scandinavian sub-programme.

Table I - Territorial impact dimensions in border regions.

Quadro II - Dimensões dos impactos territoriais nas regiões de fronteira.

\begin{tabular}{|c|c|}
\hline Dimensions & Sub-dimensions \\
\hline Socioeconomic Cohesion & $>$ Economy - Society - Culture \\
\hline Territorial Articulation & $\rightarrow$ Polycentricity (Physical - Relational) \\
\hline Institutional Building & $>$ Working Communities - Euroregions - EGTC \\
\hline Environmental Sustainability & $>$ Environment - Energy \\
\hline & $\begin{array}{l}\text { - Institutional - Urban } \\
\text { - Cultural - Social }\end{array}$ \\
\hline Reduction of Barrier Effect & $\begin{aligned}> & \text { - Environmental - Heritage } \\
& \text { - Accessibility } \\
& \text { - Economy - Technology }\end{aligned}$ \\
\hline
\end{tabular}




\section{METHOD}

To reach solid conclusions the analysis was based mainly in a qualitative approach, which required the reading of the approved SNBR INTERREG-A projects main goals, and an appropriate bibliography search. The main goal was to understand to what extent the SNBR INTERREG-A programme managed to reduce the barrier effect in its main dimensions.

For practical reasons (availability and comparison of data), the studied border area encompasses the entire border NUTS III area, which does not correspond exactly to the Swedish-Norwegian INTERREG-A intervention area (fig. 1). Then again, it is important to realise that the criteria used to divide the three border sub-regions is also slightly different from the one used in this programme.

Finally, it should be stressed that the analysis follows a regional perspective of the territory. Consequently, it does not intend to check every detail of the CBC process in this area, especially the ones concerned with local and individual contacts along the border area. Even so, the objective is to give a general idea to regional and local stakeholders, at political and non-political level, about the main outcomes of the programme in reducing the barrier effect on the border area.

It is also important to underline that this paper does not intend to resemble a typical evaluation report of the Regional European Funds, which, in the author's point of view, tends to disregard an in-depth territorial approach, by focusing mainly on the socioeconomic aspects of the analysed programmes. An evaluation rationale will be followed, focussing on one of the territorial impact evaluation's main dimensions on border regions: the reduction of the barrier effect.

\section{INTERREG-A EFFECTS ON THE BARRIER EFFECT}

According to the Committee of the Regions, $\mathrm{CBC}$ contributes to the creation of a 'Citizen's Europe', in which people learn to know one another and to understand and respect their diversity. Hence, the most important goal is to bring people together, involving local and regional authorities in order to integrate divided areas which face common problems and require common solutions (EC, 2002). In the same vein, the Association of European Border Regions (AEBR, 2000, 2008) supports the top-down approach in the process of $\mathrm{CBC}$, which involves the participation of citizens, institutions and social partners in programmes, projects and decision-making processes. At the same time, this association (AEBR, 2008:15-27) recognizes that "jointly developed programmes and projects can be most effectively implemented and realised if the regional and local partners play a considerable role", and that the "goal of cooperation and cross-border regions is to develop cooperative structures, procedures and instruments that facilitate the removal of obstacles and foster the elimination of divisive factors". 
As anticipated, the $\mathrm{CBC}$ process should have significant impacts on reducing and/or eliminating isolation induced by the presence of a 'border' or 'boundary'. When it comes to the correct use of these words, Lundén makes an attempt to clarify the differences between both of them: "In the English language, boundary and border are often being used without distinction. However boundary seems to be the most appropriate word for the line itself: a line or strip that marks or shows a limit or end (Webster)" ... "Border is defined as 'an outer part or edge' but also with synonyms frontier and boundary. Webster adds, 'a border is the area along the English-Scottish boundary'. Border thus seems to have more of an area meaning than boundary, which means the line only" (Lundén, 2004: 16). In either case, this author claims that "boundaries are necessary to maintain the set of rules valid in the decision domain" (Lundén, 2004: 210).

Yet, this artificial line acts, in many cases, as a barrier and repressive factor in many domains (culture, economic, institutional, social), since the "barrier may be seen as a particular type of obstacle which restricts or impedes the smooth transfer or free movement of a person or commodity from one place to another" (Nijkamp and Batten 1990: 233). Also, according to other authors (Hägerstrand, 1967; Abler et al., 1972; Haggett, 2001; Button and Rossera, 1990) there are many different types of barriers (physical, fiscal, institutional, technical, cultural, etc.) and the barrier effect interferes with the diffusion of the process of innovations, which, in turn, influences the outcomes and the evolution of the $\mathrm{CBC}$ process in a given border area.

Suárez-Villa (et al., 1991) suggested a typology of three types of barriers in border regions, regarding its isolation status: (i) Isolated - the border is almost isolated, however there can be some illegal trading and migration; (ii) Interconnected - the barriers are still strong, but the political structures on both sides of the border collaborate in a formal manner; (iii) Jointly Controlled - the barrier effect is very reduced, and political structures accept the sharing of social infrastructures on the border area.

Based on many of these studies, I distinguished five different analytic dimensions of the barrier effect concept: a) institutional-urban; b) cultural-social; c) environmental-heritage; d) accessibilities; e) economy-technology (Medeiros, 2010b). The evolution of each one of these dimensions in a given border area can be analysed by following the changes of the related statistical indicators (table II). 
Table II - Dimensions and indicators of the barrier effect.

Quadro II - Dimensões e indicadores do efeito barreira.

\begin{tabular}{|c|c|}
\hline Dimension & Indicators \\
\hline $\begin{array}{l}\text { Institutional } \\
\text { Urban }\end{array}$ & $\begin{array}{l}\rightarrow \text { CBC Associations and cabinets } \\
\rightarrow \text { Urban } \mathrm{CBC} \text { associations }\end{array}$ \\
\hline $\begin{array}{l}\text { Cultural } \\
\text { Social }\end{array}$ & $\begin{aligned} \rightarrow & \text { Language penetration } \\
\rightarrow & \text { Cultural initiatives and CB } \\
& \text { equipment's }\end{aligned}$ \\
\hline $\begin{array}{l}\text { Environmental } \\
\text { Heritage }\end{array}$ & $\begin{array}{l}\rightarrow \text { CB Protected areas protocols } \\
\rightarrow \text { CB Heritage initiatives }\end{array}$ \\
\hline Accessibility & $\begin{array}{l}\rightarrow \text { CB Average road traffic } \\
\rightarrow \text { Road Crossing borders }\end{array}$ \\
\hline $\begin{array}{l}\text { Economy } \\
\text { Technology }\end{array}$ & $\begin{array}{l}\rightarrow \text { CB Commerce } \\
\rightarrow \text { CB Companies }\end{array}$ \\
\hline
\end{tabular}

Under the penalty of losing detailed information which can help redraw the regional map of the border permeability evolution in the SNBR under the analysed INTERREG-A period (1994-2006), the discussion of the Programme's main effects on the barrier effect will be supported in short topics, for each of the five dimensions of this concept:

\section{a) Institutional-urban}

The different administrative and regulatory regimes (taxes, customs, etc), are usually seen as one of the most important barriers to the $\mathrm{CBC}$ between countries, and the same goes for the SNBR. As a matter of fact, this is usually mentioned by regional and local actors as the paramount barrier in this region, since Sweden belongs to the EU and Norway does not. Yet, in the last decades, important improvements in common legislation (sometimes it is enough to review small details) took place, to solve this difficulty. Additionally, the similarity of the territorial administration model in both Scandinavian countries, with high levels of governance at the local level, supports these improvements. In this respect, the INTERREG-A programme also had a positive impact in strengthening the bounds between local and regional actors, breaking the barriers and finding innovative answers for old cross-border problems.

\section{b) Cultural-social}

A curious conclusion of the evaluation report of the INTERREG II-A expresses that: "a common view is that the awareness of the important cultural differences between Sweden and Norway has grown. Many actors say they have become aware 
of differences they did not know about before they entered into the Interreg co-operation. This is reported as valuable, and has generated processes of mutual understanding that will be useful for future co-operations" (EC, 2003: 7). In spite of these differences, the neighbor language is considered to be quite accessible in general, both by Norwegians and Swedish people, since $85 \%$ of the words are similar. This justifies the absence of INTERREG-A projects in the language domain. Even so, this initiative allocated $30 \%$ of the total investment for the cultural-social dimension, by promoting the preservation of local traditions, tourism, and other cultural events (sport, music, art). On the other hand, much remains to be done in sharing public infra-structure along the border, mainly due to legislative reasons.

\section{c) Environmental-heritage}

The future of many SNBR rural areas is increasingly tied up with the preservation of environment and natural heritage and its economic value (tourism). However, there are no formal agreements between Norway and Sweden on management of their National Parks, even on the two areas where there are transboundary adjoining protected areas: (i) Femundsmarka (N) - Sånfjället (S) - Töfsingdalen (S); (ii) Tresticklan (S). Nevertheless, almost $12 \%$ of the INTERREG-A funds were used in projects related with environmental protection. On the other hand, the lack of world heritage sites (only three in the SNBR - Rock Carvings - Tanum; Copper Mining Falun; Mining Town - Røros), and other important manmade landmarks in this border area, hampers the possibilities to attract more visitors, and thus finding ways to diversify the local economy.

\section{d) Accessibility}

The level of the relational proximity between two regions or countries depends largely on the quantity and quality of the accessibilities (roads, motorways, railways and airports). In this domain, and according to the inputs gathered from local and regional actors along the SNBR, the permeability of the border has increased slightly in the last 13 years, but remains far from achieving the desired results. In fact, during this period of time there was only one new cross-border road connection (the new Svinesund bridge) in the entire border region, but a positive fact remains: the reopening of the railway connection between Trondheim and Östersund, supported by the INTERREG-A funds, which in the whole contributed with $10.5 \%$ to improve the cross-border accessibility in border area, as stated before.

\section{e) Economy-technology}

The main priority of the present INTERREG-A (IV) in the SNBR is the economic growth of the whole region also during the first two INTERREG-A phases (1995-2006), one of the main goals was the creation of new jobs, because this is the best way to preserve the population contingents in these low population density are- 
as, and that is why this dimension received the biggest piece of the investment in this programme (37\%), in order to support the local/regional economic activity, the technologic innovation and the development of competencies. However, an insight into the data related to this dimension (trade flows and penetration of neighbour country owned companies) showed that, in spite of a reasonable increase in these flows over the border, they tend to focus on the bigger market areas, and neglect most of the peripheral border areas.

In sum, and in general terms the projects approved under the Swedish-Norwegian INTERREG-A programme gave a substantial contribution to the reduction of the barrier effect in all its dimensions, both directly and indirectly, but had a stronger impact on the economy-technology and cultural-social ones (Medeiros, 2010). In this regard, it seems that the financial constraints of the programme justify the small percentage spent in improving the cross-border physical accessibilities. These constraints, however, did not affect the 'soft leverage effects' produced by the programme, in terms of increased inter-cultural understanding, strengthened cross-border governance and actors/entities mobilization, thus generating considerable institutional, social, cultural and economic added-value.

This positive picture does not imply, however, that some aspects of the programme can and should be improved. For instance, (i) by exploring the legal possibilities inherent to the creation of European Groupings of Territorial Cooperation (EGTC), (ii) by establishing and reinforcing functional cross-border urban complementarities (Medeiros, 2010); (iii) by improving the mechanisms of learning and knowledge dissemination of the programme, instead of being isolated to single projects and (iv) by better integrating the gender equality and environment issues into the programme (PANTEIA, 2010).

On the other hand, according the Nordregio evaluators, the main challenge of the programme is to 'to find ways to strategically co-ordinate the $\mathrm{CBC}$ activities of the previous three sub-programmes into one coherent whole'. The final results of this outcome remain to be seen. However, the outcomes of the first half of the on-going generation of the programme seem to prove that the centralization management process in the Swedish part of the border (Tillväxtverket, 2009) is not producing the expected results in terms of the desired percentage of approved cross-border projects and materialized investments. On the other hand, the three Norwegian sub-programmes, and especially the Inner Scandinavia one is largely ahead in this regard (more that $40 \%$ of the overall predicted investment already applied). Remarkably, it seems that there is a 'Swedish Government' versus a 'Norwegian Governance' type of cross-border battle, to establish a better strategy, in order to reach the goals of the programme and, so far, it looks like the Norwegian strategy is way ahead, mainly because their management strategy closely follows the EU principle of subsidiarity. 


\section{SEVEN INTERREG-A PROJECTS AND THEIR POSSIBLE IMPACTS ON THE BARRIER EFFECT}

The on-going Swedish-Norwegian INTERREG-A (2007-2013) is the third generation of the programme, and falls within the framework laid out for the EU Cohesion Policy third objective: European Territorial Cooperation. Its overall objective is to strengthen the attractiveness and competitiveness of the border region through cross-border cooperation for the benefit of the local people and communities, by following a sustainable socioeconomic development path.

When compared to the previous INTERREG-A generations, one major difference stands out from the slightly increase in the intervention area: Dalarna County (N) (fig. 1) is now fully covered by the programme together with 11 new Akershus municipalities, and the surrounding counties of Gävleborg (S), Västernorrland (S), Örebro (S), Oppland (N) and Oslo Municipality (N) can, through co-operation with the core area, gain access to a maximum of $20 \%$ of the programme's funds.

This new programme is structured along two main priorities: (i) economic growth, aiming to strengthen the regional productive fabric and the sustainable competitiveness of the border region, by supporting knowledge and innovation, by establishing better conditions for trade and industrial production and by improving the border accessibility; (ii) attractive living environment, with a view to increase the quality of life of border dwellers, by improve the sustainable usage of natural and cultural resources, by improving collaboration between public services (health, risk prevention and safety) and urban development.

These strategic priorities are expected to address the needs and the CBC challenges ahead and further develop the networks created in the previous generations. In this regard, the economic dimension (fist axis) is expected to receive the 'Lions Part' $-66 \%$ - of the total predicted investment (68 M€, table III), which is a clear sign of a CBC strategy that broadly seeks, first and foremost, to foster the economic fabric of the border area, in order to attract new jobs, to counteract an increasing depopulation panorama (especially in the Swedish side of the border). It is also expected an investment of between 5\% and 10\% from private partners (SN_INT, 2008).

Table III - Intervention axes and financing $(€)$ - INTERREG IV-A (S-N). Quadro III - Eixos de Intervenção e financiamento $(€)$ - INTERREG IV-A (S-N).

\begin{tabular}{lccc}
\hline Priority Axis & EU & National & Total \\
& ERDF & Public & Public \\
\hline 1 - Economic Growth & 20845275 & 17055222 & 37900497 \\
2 - Attractive Living Environment & 14145008 & 11573185 & 25718193 \\
3 - Technical Assistance & 2233422 & 2233420 & 4466842 \\
\hline Total & 37223705 & 30861827 & 68085532 \\
\hline
\end{tabular}

Overall, this programme is based both on the EU regional policy guidelines, and also in the Scandinavian countries local, regional and national development strategies. In addition, it was developed through dialogue between the inter-regional 
partnerships with the involvement of the three sub-regions, the Swedish and Norwegian governments, departments, the European Commission and other bodies, the central authorities and civil services (SN-INT, 2008).

In a wide sense, the overall aim of the INTERREG Initiative is to assist border areas in reducing their relative isolation and prevent national borders to be barriers to a sustainable and balanced development of the EU territory. To cast light upon the INTERREG-A S-N programme contribution to the reduction of barrier effect (in all its dimensions), a thorough examination of all the approved projects was made and the available statistic data related with the correspondent dimensions was analysed. To be more specific, in the following paragraphs, I examine seven of these approved projects which I had the chance to evaluate, in the first couple of weeks of March 2010.

Prior to the analysis of the 'visited INTERREG projects', it is indispensable to provide the reader with a closer inspection regarding their main objectives:

a) Green Project - Sälun establishes a borderless energy cooperation project between Ski Resorts in the cross-border region during three years. Norwegian Ski Resorts: Trysilfjell and Fulufjell (Municipality of Trysil); Swedish Ski Resorts: Sälen, Kläppen, Stöten and Idre.

b) Innovation Music Network-Hamar and c) Innovation Music Network-Falun enable business in the music industry to grow and develop. Expand the network into an innovation system through relating research and education to the trade and business community (Karlstad, Falun, Hamar/Rena).

d) Renewable energy-Börlange and e) Renewable energy - Lillestrøm develop the region's skills and also contribute to increased research in renewable energy and energy efficiency. This project is also expected to encourage the formation of new companies and services in the area, and increase the interest in environmental issues (Värmland and Dalarna in the Swedish side of the border and Akershus and Hedmark in Norway).

f) Turning territorial diversity into strength, studying the opportunities and challenges for the region of Inner Scandinavia related to on-going regionalization / regional augmentation to the increased importance of attractiveness for residents and globalization. In this project we cooperate with the Centre for Research on Regional development at Karlstad University and the College of Dalarna (Hauge et al., 2010).

g) Competence attraction - Börlange. The project has the purpose of promoting good cooperation between employers in the regions of Dalarna and Hedmark and to establish and develop a concept based on pilot recruitment, tailored to small and medium-sized business in the Hamar region and Mitt Dalarna, among other realizations (seminars, networks of employers, cross-border enterprises links, etc).

As expected, the majority of the themes of the previous projects are centred in the inter-locking themes of $\mathrm{R} \& \mathrm{D}$, training/qualifications, joint elaboration of studies, environment/energy and support business environment, which goes according to the low degree of isolation and advanced level of cooperation, which characterizes 
the SNBR, at the present moment. The question is: are they producing long term positive and sustainable effects in reducing the barrier effect along the border area?

In short, the general opinion of many interviewed INTERREG-A project leaders is that the physical distances are still a source of isolation and improvements of cross-border transports are needed in this area (Inner Scandinavia). In this sense, it is only logical that the 'accessibility' dimension of the barrier effect was highly neglected in the seven projects. By contrast, most of the analysed projects contribute to the reduction of the 'economic/technology' dimension of the barrier effect, by promoting cooperation between business activities.

Finally, given all the information collected, I conclude that some of the seven INTERREG analysed projects also contributed to strengthen the institutional networks between regional and local actors, as well as to promote social and cultural collaboration, and to establish new forms of collaboration on environmental issues (table IV).

Table IV-Contribution of the projects to the barrier-effect reduction.

Quadro IV - Contribuição dos projectos para a redução do efeito barreira.

\begin{tabular}{|c|c|c|c|c|c|}
\hline & W $\quad \mathrm{M} \quad \mathrm{S}$ & W M S & W M S & W M S & W M S \\
\hline Institutional & $\square \square \square$ & $\square \square \square$ & $\square \square \square$ & $\square \square \square$ & $\square \square \square$ \\
\hline Economic/Technology & $\square \square \square$ & $\square \square \square$ & $\square \square \square$ & $\square \square \square$ & $\square \square \square$ \\
\hline Cultural/Social & $\square \square \square$ & $\square \square \square$ & $\square \square \square$ & $\square \square \square$ & $\square \square \square$ \\
\hline Environment/Heritage & $\square \square \square$ & $\square \square \square$ & $\square \square \square$ & $\square \square \square$ & $\square \square \square$ \\
\hline Accessibility & $\square \square \square$ & $\square \square \square$ & $\square \square \square$ & $\square \square \square$ & $\square \square \square$ \\
\hline Project & $\mathrm{a}$ & $\mathrm{b}+\mathrm{c}$ & $\mathrm{d}+\mathrm{e}$ & $\mathrm{f}$ & $\mathrm{g}$ \\
\hline
\end{tabular}

\section{CONCLUSION}

The boundary between Norway and Sweden is one of the longest in the world between two states (Lundén, 2004), but it was far from being a static and highly isolated type of border in the pre-INTERREG-A period like, for instance, the border between Portugal and Spain. Even so, each side of the border developed its own administrative practices and has gone its own economic way since Norway became independent in 1905. Half a century later, the Nordic countries decided to establish a more formal and fruitful process of cross-border approximation, both on the national and on the regional levels. Consequently, when INTERREG-A between Sweden and Norway was initiated (1994), the degree of isolation in the border area between both countries was already low, compared with many other European borders. In addition, the Nordic INTERREG programmes have been in the making for decades (Nordregio, 2007), thus contributing to the establishment of a long-standing tradition in cooperation between the Nordic border nations and regions. 
In spite of this largely positive scenario, which helped to attain a particularly high level of integration in programme management structures and procedures, since the first INTERREG-A generation (1994-1999), the centre-south part of the border region between Sweden and Norway, which is covered by the European Initiative studied in this paper, still suffers from lack of economic opportunities in many areas, dissimilar fiscal and social legislation, diverging wage structures, uneven quality of infrastructures, (Berger and Ørbeck, 2006), cultural differences, lack of public transport connections, etc.

In this context, the launching of the INTERREG-A programme in this region became an opportunity to accelerate the cross-border contacts in order to mitigate some of the discussed weaknesses of the border area, mainly because it brought an additional financial package that revitalized the process of cross-border cooperation between both sides of the border area. This raises some issues concerning the effective territorial impacts that this EU initiative produced so far in this region. Hence, this paper intends to provide a short overview of the main effects INTERREG-A programme in reducing the barrier effect in all its dimensions, in the border area.

In a wide sense, the overall aim of the INTERREG Initiative is to assist border areas in reducing their relative isolation and prevent national borders to be barriers to a sustainable and balanced development of the EU territory. To cast light upon the impact of the Swedish-Norwegian programme in reducing the barrier effect, in all its dimensions (institutional-urban, accessibility, culture-social, environmental-heritage and economy-technology), I examined the approved INTERREG-A projects and the available statistic data related with the correspondent dimensions. Furthermore, I looked upon seven specific projects which I had the chance to evaluate in an in-depth mode. In this regard, our overall findings show that the border permeability has been increasing in all the studied dimensions, since the beginning of the first INTERREG-A generation, and this initiative has produced significant outputs to reduce the barrier effect in all of them, directly or indirectly, but had a stronger impact on the economy-technology and cultural-social dimensions in this border area.

In conclusion, the results show that the territorial impacts of the Swedish-Norwegian programme have been extremely positive, in a limited budget context (1/10 of the funds received by the Portuguese-Spanish programme, in absolute ter$\mathrm{ms}$ ), and a co-operation scenario between a EU and a non-EU country. In fact, the additionality of the programme is regarded to have one of the highest values in the European context (EC, 2007: 119). At the same time, significant improvements have been made by the programme Managing Authorities and the Joint Technical Secretariats, in order to choose the most appropriate cross-border projects, which can produce higher levels of outputs and territorial impacts in the development path of the border area. This requires a constant process of project evaluation and also INTERREG secretariat staff education/formation. Concerning the latest, I am witness of the professionalism and quality of many of the Swedish-Norwegian INTERREG-A managing structures, which use every opportunity to constantly update their knowledge concerning the cross-border cooperation process, either within the Scandina- 
vian borders, or outside those borders, in study trips intended to learn from other European on-going cross-border experiences.

\section{ACKNOWLEDGEMENTS}

The author wishes to thank the valuable contributions of two anonymous referees, and Graça Roenning, which were of key-importance in improving this article.

\section{REFERENCES}

Abler R, Adams J, Gould P (1972) Spatial diffusion: meshing space and time. In Englewood Cliffs (ed.) Spatial Organization, London, Prentice-Hall International: 389-422.

AEBR (2008) Cooperation between European Border Regions. AEBR - NOMOS, Baden-Baden.

AEBR (2000) Practical guide to Cross-Border Cooperation. Third Edition 2000, Phare, Association of European Border Regions (AEBR), Gronau.

Berger S, Ørbeck M (2006) Grensein og Grense-SWOT. Analyser grenseregionene innenfor, Eus Mål 3 Europeisk Territorielt samarbeid 2007-2013, Sverige-Norge-programmet, Karlstads universitet och Østlandsforskning, Karlstad.

Button K, Rossera F (1990) Barriers to communication. A literature review. The annals of regional science, 24(4): 337-357.

EC (2007) Growing Regions, Growing Europe. Fourth report on economic and social cohesion. European Commission, Brussels.

EC (2005) Programme summary of the Sweden-Norway INTERREG III-A programme, INTERACT, Stockholm.

EC (2003a) Mid-term evaluation of Interreg III-A Sverige - Norge. NUTEK, Stockholm.

EC (2003b) Slututvärdering av Interreg II-A - programmem - Sverige - Norge. NUTEK, Stockholm.

EC (2002) Opinion of the Committee of the Regions on 'Strategies for promoting cross-border and interregional cooperation in an enlarged $\mathrm{EU}$ - a basic document setting out guidelines for the future. Official Journal of the European Communities, (2002/C 192/09), Brussels.

Haggett P (2001) Geography a global synthesis. Prentice Hall, Essex.
Hägerstrand T (1967) Innovation diffusion as a spatial process. University of Chicago Press, Chicago.

Lundén T (2004) On the boundary, about humans at the end of territory. Södertörns Högskola, Huddinge.

Medeiros E (coord.) (2010a) The Cross-Border Cooperation between Sweden and Norway INTERREG-A Territorial Impacts (1994-2006). CEG, NEST, Lisbon.

Medeiros E (2010b) A cooperação transfronteiriça Portugal-Espanha e Suécia-Noruega. Dissertação de Doutoramento, IGOT, Universidade de Lisboa, Lisbon.

Nijkamp P, Batten D (1990) Barriers to communication and spatial interaction. The annals of regional science, 24(4): 233-236.

Nordregio (2007) Territorial cooperation - extending interaction. Regional Development in the Nordic Countries, 1: 89-96.

NUTEK (2003) Grenseoverskridende samarbeid har gitt mersmak - Slututvärdering av Interreg IIA - programmem - Sverige - Norge. NUTEK, Stockholm.

PANTEIA (2010) INTERREG III Community Initiative (2000-2006). Ex-Post Evaluation - Final Report, Zoetermeer.

SN_INT (2008) Borderless cooperation: we strengthen you. You strengthen the region. INTERREG-A Sweden-Norway leaflet, Östersund.

Suárez-Villa L, Giaoutuzi M, Stratigea A (1991) Barrieras territoriales y fronterizas en redes de información y comunicación. Estudios Territoriales, 37: 69-83.

TILLVÄXTVERKET (2009) Interreg IVA Sverige Norge. Evaluering av gjennomføringsorganisasjonen. Klicka och skriv rapportnummer, Tillväxtverket, Östersund. 